\title{
Peripheral Nerve Schwannomas: A Literature Review
}

\section{Schwannomas de Nervos Periféricos: Revisão da Literatura}

\author{
Marcelo José Silva Magalhães ${ }^{1}$ Douglas Vitor Maia Pereira ${ }^{2}$ Henrique Nunes Pereira Oliva ${ }^{3}$ \\ Dayane Tabatha Santos Durães ${ }^{2}$ Fernanda Leal Caiado ${ }^{2}$ Grazielle Mendes Araújo ${ }^{2}$ \\ Enilton Teixeira Freitas Junior ${ }^{2}$
}

${ }^{1}$ Department of Neurology, Hospital Vila da Serra, Belo Horizonte,

Minas Gerais, Brazil

2 Department of Neurology, Faculdades Unidas do Norte de Minas-

FUNORTE, Montes Claros, Brazil

${ }^{3}$ Department of Neurology, Faculdades Integradas

Pitágoras-UNIFIPMOC, Montes Claros, Brazil

Arq Bras Neurocir 2019;38:308-314.

\begin{abstract}
Address for correspondence Marcelo José da Silva de Magalhães, MD, MSc, Rua Francisco Versiane Ataide, $n^{\circ} 760$, apartment $n^{\circ} 1301$., Montes Claros, MG, 39401-039, Brazil

(e-mail: marcelo7779@yahoo.com.br).
\end{abstract}

\begin{abstract}
Keywords

- schwannomas

- peripheral nerves

- neuroanatomy

- neurosurgery
\end{abstract}

\section{Resumo}

Introduction Schwannomas are benign tumors originating from the cells, which wrap around axons that are usually encapsulated and solitary. These tumors usually lead to little or no symptomatology. They are usually the most common peripheral nerve tumors in adults, with their highest incidence between the third and fifth decades of life.

Objective To perform a review about schwannoma of the peripheral nerves, presenting its definition, epidemiology, diagnosis, symptomatology and treatment.

Methodology This is a descriptive work, based on a review of articles available in the PubMed database with the descriptors schwannoma and peripheral nerves.

Results and Discussion Only papers published between 1981 and 2019, describing studies in humans, and that were available as full articles were selected. A total of 391 articles were included; after reading the titles, we noted that 67 articles fit the topic of the present study. Among the articles selected for reading, 33 fit the objectives of the present work, and were considered for the writing of the present article.

Conclusion Schwannomas are benign myelin sheath tumors that develop with local symptomatology or asymptomatic and present a good surgical prognosis with generally reduced rates of surgical complications.

Introdução Os Schwannomas são tumores benignos originados das células de Schwann que envolvem os axônios de nervos periféricos. Esses tumores são encapsulados e solitários que geralmente levam a pouca ou nenhuma sintomatologia. Eles são os tumores de nervos periféricos mais comumente encontrados em adultos, com maior incidência entre a terceira e quinta décadas de vida.

Objetivo Realizar uma revisão sobre o schwannoma de nervo periférico, apresentando sua definição, epidemiologia, diagnóstico, sintomatologia e tratamento.

Metodologia Este é um trabalho descritivo, baseado na revisão de artigos disponíveis na Base de dados PubMed, a partir dos descritores: schwannoma e nervos periféricos.

received

March 5, 2019

accepted

August 6, 2019
DOI https://doi.org/

10.1055/s-0039-1698786. ISSN 0103-5355.
Copyright (e 2019 by Thieme Revinter

Publicações Ltda, Rio de Janeiro, Brazil
License terms

()(1) $\Theta \circledast$ 

Palavras-chave
- Schwannomas
- nervos periféricos
- neuroanatomia
- neurocirurgia

Resultados e Discussão Somente os artigos publicados entre os anos de 1981 e 2019, estudos envolvendo humanos e que estavam disponíveis como artigos completos, foram selecionados para a revisão. Um total de 391 artigos foram incluídos, após ler os títulos apenas 67 artigos se enquadraram no tópico do presente estudo. Entre os artigos selecionados para leitura, 33 se enquadram nos objetivos do presente trabalho e por isso foram considerados para a redação do presente artigo.

Conclusão Os Schwannomas são tumores benignos da bainha de mielina que se desenvolvem com sintomatologia local ou ausência de sintomas e que apresentam bom prognóstico cirúrgico, com taxas usualmente reduzidas de complicações cirúrgicas.

\section{Introduction}

Most peripheral nerve sheath tumors (PNSTs) correspond to schwannomas, which are also known as neurilemomas or neurinomas. They are benign tumors, usually solitary, which develop and reach sizes between $1.5 \mathrm{~cm}$ and $3 \mathrm{~cm}$ in diameter; there is also the possibility of presentation as several tumors following the same path of the nerve. In most cases, these tumors consist of well-differentiated Schwann cells, and the occurrence of malignant transformation is rare. ${ }^{1}$

Epidemiologically, they are the most common peripheral nerve tumors in adults; they usually occur when the individual is between 30 and 50 years old, with no significant difference regarding ethnicity or gender. They comprise $\sim 8 \%$ of all intracranial tumors, and $\sim 29 \%$ of spinal tumors. About 12 to $19 \%$ of the cases of schwannoma occur in the upper extremity of the body, while 13.5 to $17.5 \%$ of the cases occur in the lower extremity. ${ }^{1}$

The present work aims to perform a literature review about schwannoma of the peripheral nerves, describing its definition, epidemiology, symptomatology, diagnosis and surgical treatment.

\section{Methodology}

The present is a descriptive work, based on review of articles available in the PubMed database with the descriptors schwannoma and peripheral nerves. Only papers published between 1981 to 2019, focusing the on peripheral nerves, were selected. Studies focusing on the cranial nerves were excluded. Reference books on the subject were also used.

\section{Results}

A total of 391 articles were included; after reading the titles, we noticed that 67 fit the topic of the present study. Among the articles selected for reading, 33 fit the objectives of the present work, and were used to support the writing.

\section{Discussion}

\section{Definition}

Schwannomas are tumors that arise from Schwann cells and are characterized by slow growth, which can create a capsule around the lesion. They are typically composed of welldifferentiated Schwann cells., ${ }^{2,3}$ (- Fig. 1)

Schwannomatosis is a genetic disease characterized by the development of multiple peripheral tumors. ${ }^{4}$

\section{Epidemiology}

Less than $5 \%$ of the tumors of the extremities are PNSTs. ${ }^{5}$ Studies have shown a disproportionately greater incidence of schwannomas in the upper extremities (the head and neck, involving the spinal nerves and the brachial plexus), which is double that of those in the lower extremity; this is in contrast with neurofibromas, which are equally distributed throughout the nervous system., ${ }^{5,6}$ Only 1 to $3 \%$ of the schwannomas occur in the pelvis. In addition, the involvement of the

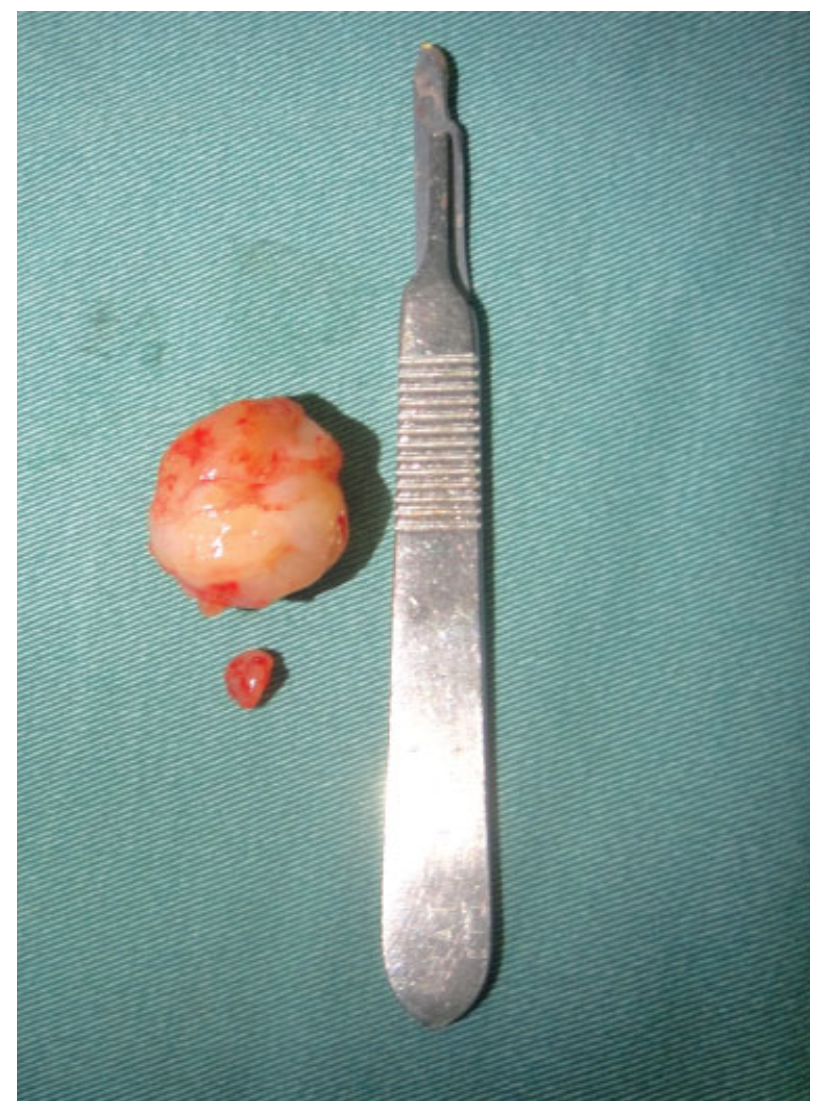

Fig. 1 Macroscopic aspect of the schwannoma. 
obturator nerve is extremely rare, with only nine cases reported in the literature in English. ${ }^{7}$

Although all ages can be affected, schwannoma is the most common peripheral nerve tumor in adults, whereas pediatric cases are rare. They have a peak incidence in individuals between 30 and 60 years old, with an incidence of 0.3 to 0.4 cases per 100,000 people per year. Most studies do not show gender preference, but some series show a predominance of female intracranial tumors. ${ }^{2,5,8}$

Schwannomas can be benign or malignant; benign tumors are the most common tumors of the peripheral nerves, and recurrence or malignant transformation rarely occurs. When they occur, recurrences are more common (30-40\%) regarding the cellular schwannomas of the intracranial, spinal and sacral regions. ${ }^{2,3,9}$

\section{Clinical Manifestations}

The schwannoma originates from the nerve sheath, and can occur anywhere within the peripheral nervous system. It is often asymptomatic, and may occasionally present only as a small palpable tumor mass, with few or no neurological deficits. ${ }^{5}$

It usually becomes symptomatic secondary to nerve compression and local mass effect. The symptoms depend on the location, with radiculopathy being the most frequent initial symptom, followed by paresthesia and limb weakness. ${ }^{10}$

When large nerves are affected, the tumor has characteristically eccentric growth, and the nerve is displaced toward the periphery. Clinically, Schwannomas can mimic a lipoma or a ganglion at the skin level. ${ }^{3,5,8}$

Schwannoma of the tibial nerve or sciatic nerve, for example, can mimic the radicular pain in the legs, which can lead to an erroneous diagnosis of radiculopathy. ${ }^{11}$

Involvement of the brachial plexus is uncommon, and usually presents as a palpable, slow-growing, supraclavicular or axillary mass, usually without pain or neurological signs. ${ }^{3}$

Predictors of malignancy include rapid tumor growth, positive predictive value (PPV) of 95\%, and presence of any loss of neurologic function (PPV of 73\%), which probably reflects nerve injury. The pain, however, can be observed in $75 \%$ of all peripheral nerve sheath tumors, and its PPV for malignancy is between $20 \%$ and $30 \%$. Nonetheless, when considering the character of pain, resting pain is more likely to be observed in schwannomas, which are believed to be caused by the release of substances that stimulate pain receptors. ${ }^{12}$

\section{Histopathology}

Schwannoma is generally composed primarily of Schwann cells that possess moderate amounts of eosinophilic cytoplasm with no discernible cell borders. Schwann neoplastic cells are arranged in two patterns.

The Antoni A pattern is represented by areas of compact, elongated cells with occasional nuclear palisades. In Antoni A tissue, there are normochromic spindle-shaped or round nuclei similar in size to smooth, tapered rather than closed muscle cells. In this pattern, the tumor cells are very close together, forming nuclear palisades (Verocay bodies), which are alternating parallel lines of tumor cell nuclei with densely-aligned cellular processes. ${ }^{5}$ All tumor cells have a pericellular reticulin pattern corresponding to the surface soil membranes.

In Antoni B tissue, tumor cells have smaller nuclei, generally round to ovoid, and are arranged freely. Collections of lipidloaded cells may be present within the Antoni A or B tissues. ${ }^{2}$ It is also noted that the B pattern consists of fewer cells, whose textures are superficial, with indistinct processes and variable lipidization. ${ }^{2}$ In contrast to schwannomas, neurofibromas do not contain Antoni A and Antoni B regions, and are less likely to show myelogenous and degenerative areas. ${ }^{12}$ Secondary degenerative changes of the tumor can be shown and characterized by the formation of cysts, hyalinization, hemorrhage and calcification. However, degeneration of the ossification is extremely rare. ${ }^{13}$

\section{(-Fig. 2)}

Examples of nuclear pleomorphism such as bizarre forms with cytoplasmic nuclear inclusions ("old schwannoma") and occasional mitotic figures may occur, but should not be considered as indications of malignancy. Malignant transformation rarely occurs in conventional schwannomas. ${ }^{2}$

Schwannomas, immunohistochemically, show strong positivity to proteins, including S-100, vimentin and CD56, and negativity to desmin, smooth muscle myosin, SMA, CD34 and CD117. ${ }^{5,13}$ In both histological patterns of Schwannomas, the $\mathrm{S}-100$ protein is positive and essential to establish the diagnosis. ${ }^{3}$

One of the types of these tumors is the schwannoma cell. This variant is hypercellular, composed exclusively or largely by Antoni A tissue, and has no Verocay bodies. ${ }^{14}$

Melanocytic schwannoma consisting of cells with ultrastructure and the immunophenotype of Schwann cells contains melanosomes, reactivity to melanoma markers, heavy melanin deposition, presence of psammoma bodies, nuclear pleomorphism and low mitotic rate. ${ }^{15,16}$ Hyperchromasia and macronuclei are common cytological atypia, unlike the reticulin pattern that is generally poor in this subtype. ${ }^{2}$

Melanotic Schwannoma is a rare primary tumor, predominating in spinal and paraspinal nerves, with a global prevalence of less than $1 \%$ of primary PNSTs. It is a rare tumor that usually involves roots of the spinal nerves, but may also present in other anatomical sites. The recent publication of the largest series of cases ${ }^{15}$ suggested that it was a separate entity from other schwannomas, and that its reclassification to a malignant lesion is considered.

\section{Genetics}

Extensive analyses have shown that the NF2 gene acts as a tumor suppression gene, and is an integral part of the formation of Schwannomas, with the inactivation of the NF2 gene detected in $\sim 60 \%$ of these tumors. ${ }^{17-22}$ These genetic events are predominantly small frameshift mutations that result in truncated protein products. ${ }^{23}$

In most cases, such mutations are accompanied by the loss of the other allele on chromosome 22q. Still, other cases demonstrate loss of the 22q chromosome in the absence of detectable NF2 gene mutations. However, loss of expression of the Merlin gene, demonstrated by Western blot or immunohistochemistry, appears to be a universal finding in schwannomas, regardless of its mutation or allelic status, suggesting that disruption of the 


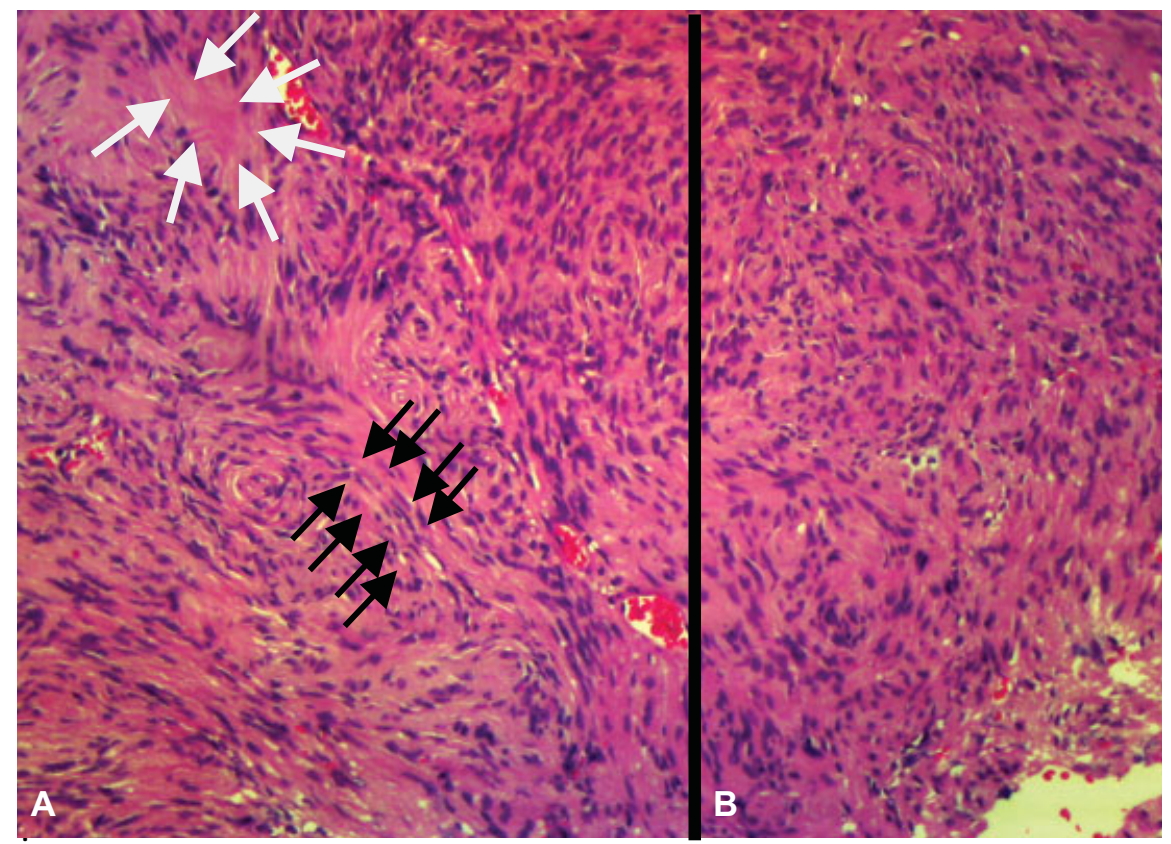

Fig. 2 Schwannoma staining eosin hematoxylin. The white-colored arrows point to a region with less cellularity compatible with a Verocay body. (A) An area of Antoni A due to the presence of Verocay body and palisade pointed by black arrow. (B) An area of Antoni B in which there is no predominance of palisade area or Verocay body.

Merlin gene function is an essential step in schwannoma oncogenesis. $^{24-26}$

Mutations of the Merlin tumor-suppressor gene cause the development of multiple tumors of the nervous system, one being schwannoma. The Merlin gene is known to be involved in the regulation of a variety of cell signaling pathways to control cell matrix adhesion, proliferation and survival. The benign nature of tumors deficient in Merlin makes them relatively insensitive to conventional chemotherapy, with invasive surgery or radiosurgery being the main therapeutic options. ${ }^{27}$

The Axl, Tyro3 and Mer (TAM family) receptors have a high expression in the TAM family receptors, so that Axl, Tyro3 and Mer are expressed at higher levels in the schwannoma when compared with normal Schwann cells. The expression of the Axl and Tyro3 receptors, but not Mer, was diminished by the reintroduction of the Merlin gene. ${ }^{27}$

The relevance of the Axl receptor in tumors deficient in the Merlin gene is marked by findings demonstrating that such a receptor is down-regulated by the Merlin gene and positively by the E3 ubiquitin ligase CRL4DCAF1. The Merlin gene appears to inhibit E3 ubiquitin ligase, which is responsible for changes in tyrosine kinase receptor expression in tumors with this gene. ${ }^{27}$

Other genetic alterations are rare in schwannomas, although a small number of cases with loss of chromosome $1 \mathrm{p}$, gain of $9 q 34$, and gain of $17 q$ have been reported. ${ }^{28,29}$

In patients with type-2 neurofibromatosis, it is important to remember which schwannomas can form along the course of the peripheral nerve and provoke peripheral neuropathies. Nodular subcutaneous schwannomas are identified in $~ 40 \%$ of patients, and often cause pain and may produce pain during palpation. In this group of patients, symptomatic lesions of the peripheral nerves are mainly treated by surgical resection. ${ }^{21}$

\section{Diagnostic Imaging}

All of the imaging modalities presented here are useful in the preoperative diagnosis of schwannomas; however, each of these methods has limitations in distinguishing the different types of tumors from the nerve sheath and establishing a differentiation between benign and malignant lesions. ${ }^{11}$ Although they do not have specificity, they are endowed with a certain diagnostic value, and some radiological characteristics can help doctors differentiate these tumors, helping to guide their approach. ${ }^{13}$

\section{Ultrasonography}

On ultrasonography (US), most PNSTs, including schwannomas, are hypoechogenic and have posterior acoustic reinforcement, making them look like a ganglion cyst, which can also be observed in other tumors of uniform cellularity, such as lymphomas. ${ }^{5,11,12}$ The presence of blood flow on the Doppler can distinguish a PNST from a cystic lesion. ${ }^{5}$

On US, schwannomas appear as well-defined, ovoid, heterogeneous masses together with cystic degeneration and eccentric location. ${ }^{11}$ Although magnetic resonance imaging (MRI) and US can be used to aid in the differentiation between benign and malignant tumors, these techniques are not consistently reliable; however, it is possible to identify signs of degeneration of long-standing tumors by features such as calcifications. ${ }^{5,12}$ (- Fig. 3)

\section{Computed Tomography}

On computed tomography (CT), the typical Schwannoma is characterized as an oval-shaped lesion with soft tissue density, heterogeneous, generally with well-defined limits, established by the encapsulation, and they may also present cystic degeneration. ${ }^{3,13}$ 


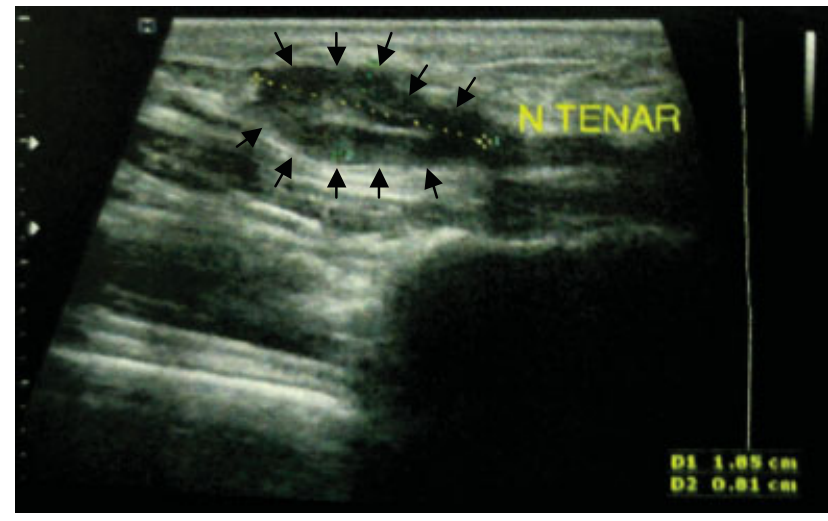

Fig. 3 Note the ultrasonographic aspect of the schwannoma of the median nerve (black arrows). This tumor presents a well-defined limit in this modality of examination. Schwannomas are hypoechoic on ultrasonography.

Some histopathological features of schwannomas may be reflected radiological patterns in tomography images. High cellularity of Antoni A areas produce as inhomogeneous images due to the increased lipid content. On the other hand, Antoni B areas can present cystic/multiseptate components and reveal hypodensity due to loose stroma and low cellularity $^{13}$ ( - Fig. 4A and 4B).

\section{Magnetic Resonance Imaging}

The MRI enables the identification and characterization of lesions with neural involvement, their relation to important anatomical structures, and the extent of intrinsic or extrinsic nerve involvement. ${ }^{5,11,12}$ The lesion is typically visualized as a well-defined mass of fusiform shape, located within the nerve, iso- or hypointense in the signal related to the skeletal muscle in T1-weighted images, and with increased signal intensity and slightly heterogeneous in T2-weighted images ${ }^{11,13}$ (- Fig. 5A and $\mathbf{5 B}$ ).

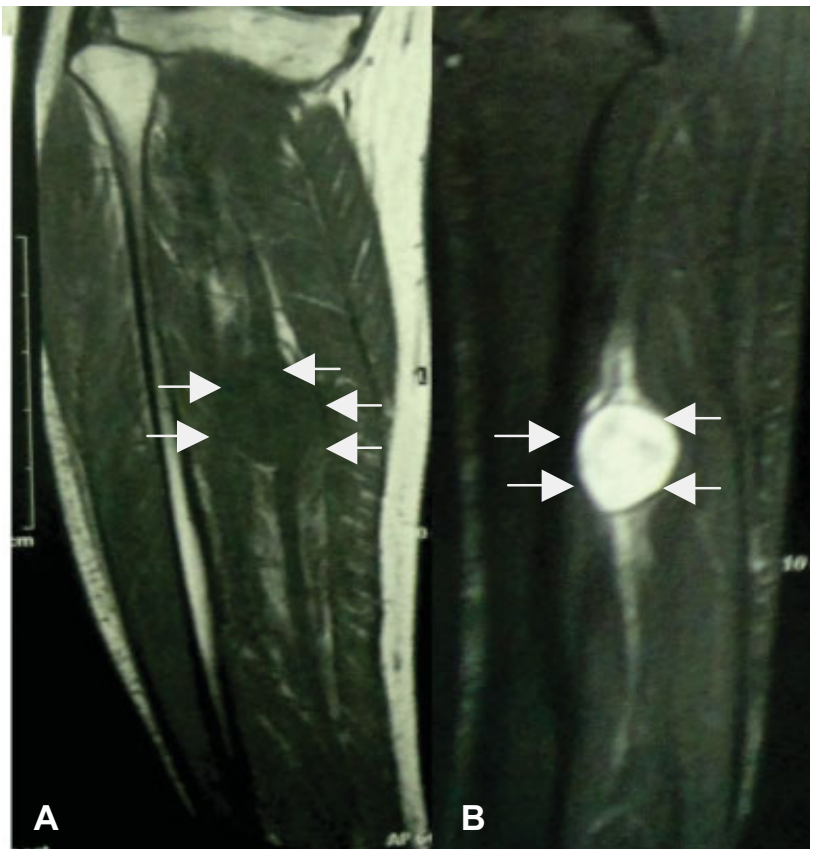

Fig. 5 Magnetic resonance imaging scan of the right lower limb (T1 and T2 respectively). (A) Normal tibial nerve (black arrows) and the hypointense tumor (white arrows). (B) Enhancement of the tumor with gadolinium.

Postcontrast enhancement in T1-weighted images is considered a defining characteristic of schwannomas. The pattern of this enhancement is characteristically non-homogeneous, with a prominence at the periphery of the lesion. Whether on the MRI or US, cystic changes can be observed and probably represent fluid secretion from tumor cells or areas of the tumor where cell growth has surpassed the blood supply. ${ }^{3}$

Another benefit of the MRI is the possibility of differentiating between neurofibromas and schwannomas based on characteristic findings and an understanding of the intraneural

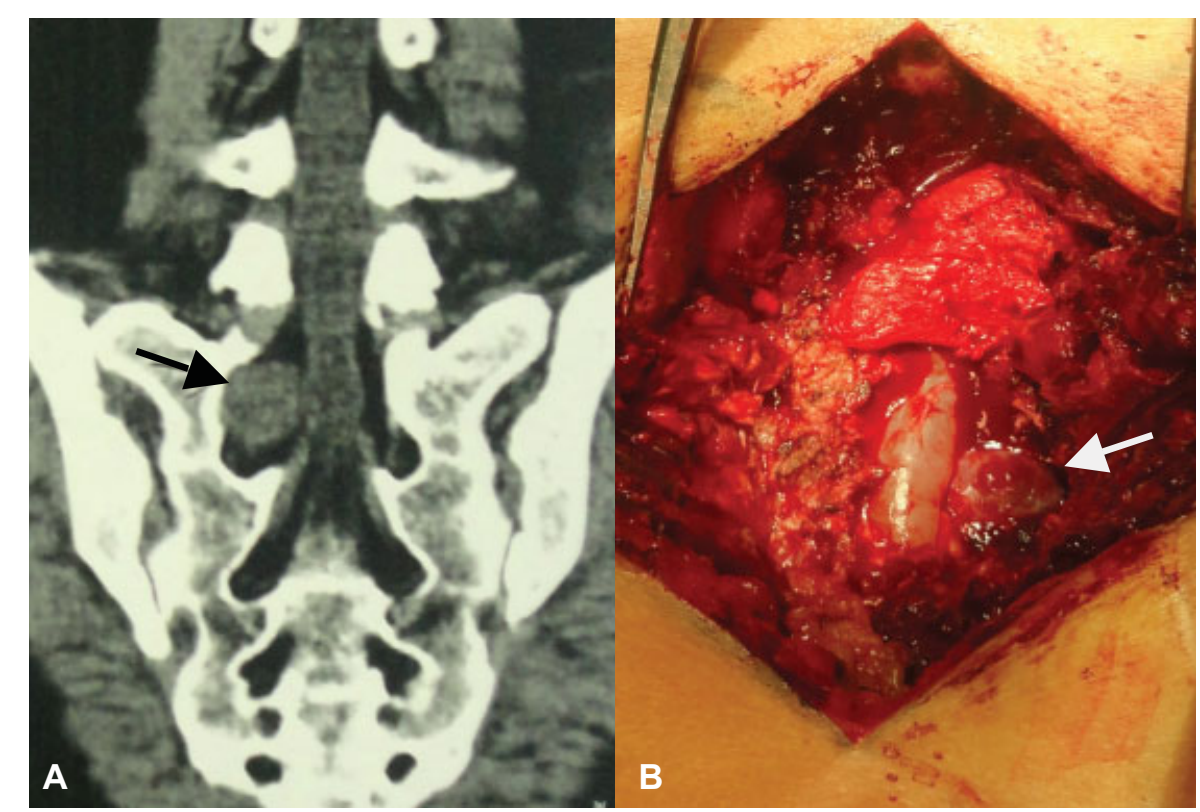

Fig. 4 (A) Computed tomography of the lumbosacral spine in a coronal section. The black arrow points to Schwannoma of the spinal nerve S1 on the right. (B) Notice the same intraoperative tumor (white arrow). 
anatomy. Schwannomas are usually encapsulated and eccentrically located, while neurofibromas are usually located centrally in the nerve sheath and have fascicles that span the tumor, often spreading it in a fusiform fashion. These most commonly demonstrate a target signal, which is a peripheral hyperintense ridge and a central hypointense region in T2-weighted MRI. Schwannomas, more frequently, present a diffuse increase in contrast in the T1 sequence of the MRI. ${ }^{5}$

Although the reliability of imaging techniques in the differentiation of benign and malignant neurogenic tumors is not fully established, certain magnetic resonance characteristics may suggest malignancy, such as large volume tumors, perilesional edema, and intratumoral cystic changes ${ }^{12}$ (- Fig. 5A and 5B).

\section{Tractography}

The treatment is a technology that enables, through the MRI, the visualization of the cerebral tracts. The construction of the MRI can be performed using conventional anatomical techniques and diffusion-based functional techniques that have the potential to overcome the limitations of the conventional MRI due to its ability to analyze the microstructure of the tissue. ${ }^{30,31}$

An important goal of the surgical treatment is the maintenance of intact limb involvement, with free and tumor-free resection margins, resulting in an oncologically safe preservation of the peripheral nerve. Thus, the treatment represents an extremely valuable tool for the preoperative evaluation of these tumors due to its excellent contrast to soft tissues and its potential to acquire structural image data and to identify where the motor fascicles are passing in the peripheral nerve structure. $^{31}$

The topographic relationship between the peripheral nerve and the tumor can be unequivocally visualized in the treatment, even in the presence of an important alter- ation of the regional anatomy. In schwannomas, the tumor characteristically originates in the sheath of only one fascicle (main fasciculus or "mother"), leaving the main trunk of the peripheral nerve connected to the mass, and the perception of this topographic relation proves to be particularly important. Thus, a spatial description detailing the location of the motor nerve and the PNST may be extremely valuable to plan the elective surgery for otherwise benign lesions. It is important to state that tractography is a neuroimage exam still restricted to specialized centers, and it presents a practical limitation regarding its use as an elective exam. ${ }^{31}$

\section{Treatment}

\section{Surgery}

Schwannomas can be resected and evolve with reasonable morbidity, although microscopic enlargement is indicated to avoid damage to nerve fibers. Surgery is successful, with preservation of neurological function in $90 \%$ of schwannomas, $80 \%$ of neurofibromas, and $66 \%$ of neurofibromas in those with type- 1 neurofibromatosis. ${ }^{5}$

Patients whose schwannomas are treated by excision with intracapsular enucleation may evolve with sensory and/or motor dysfunction, but few develop long-term neurological deficits. Approximately $80 \%$ of patients who have benign tumors experience improvement or complete resolution of pain. Patients who have already undergone biopsy or surgery often have less satisfactory results. Recurrences are quite rare when complete resection is performed. The tumor may be enucleated from the nerve without lesion to the nervous fascicles, except for the one that originated the tumor. ${ }^{5}$ (-Figs. 6A-6D)

When resection is performed by experienced surgeons, these tumors can be achieved in both superficial and deep sites, including the brachial plexus, lumbosacral plexus, and

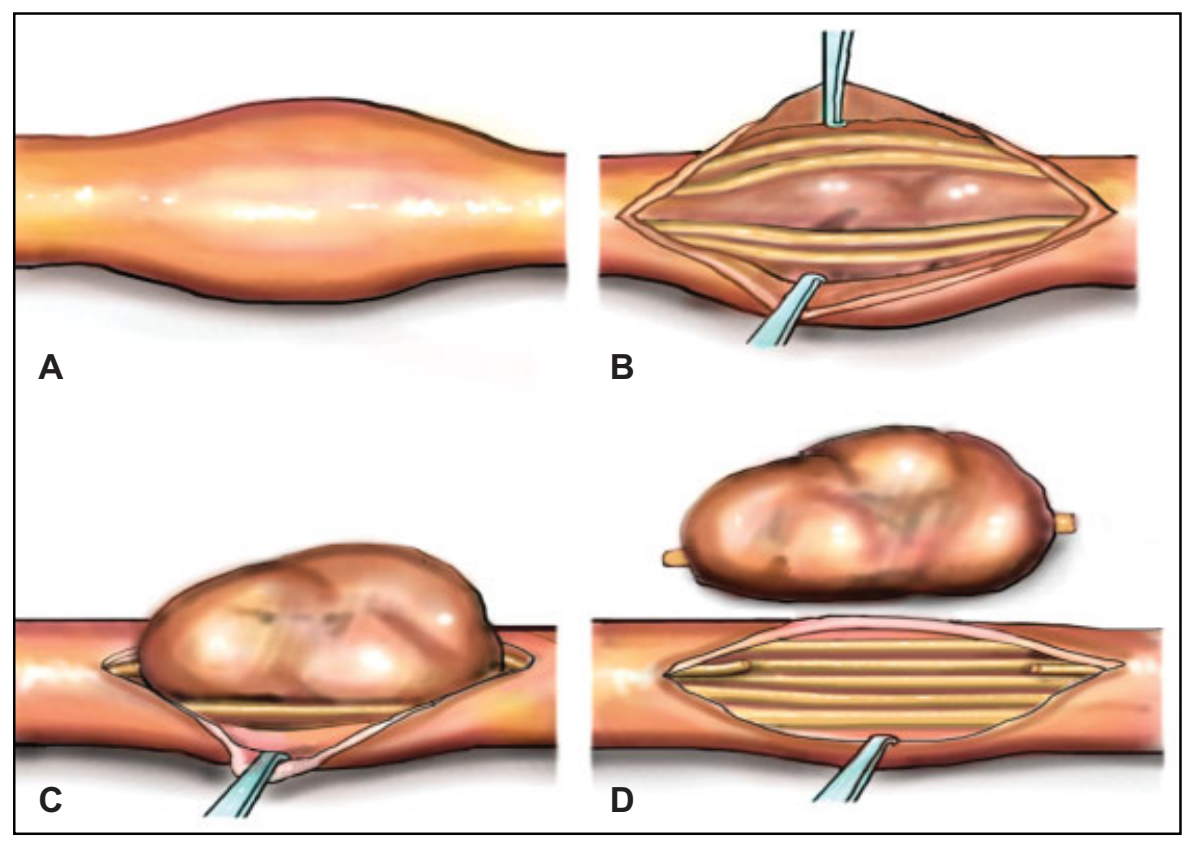

Fig. 6 (A) Schwannoma causing bulging in the peripheral nerve. (B) After the opening of the epineurium, it is possible to identify the presence of the tumor involved by viable nervous fascicles. (C) After the correct dissection of the tumor, the fascicles were removed peripherally to preserve them. (D) Complete excision of the Schwannoma is noted with sacrifice only of the bundle that originated it. Source: Marcelo Magalhães and Henrique Oliva. 
paraspinal region. Neighborly nervous elements must be mobilized and preserved, and should be identified and protected proximally and distally to the tumor itself before the direct resection attempt. Intraoperative electrophysiology or nerve stimulation may help to identify safe areas in which dissection can be performed, so it assists in the determination of functional and nonfunctional fascicles and facilitates tumor resection. 5,32

There are already descriptions of the resection of schwannomas through the endoscopic technique for the obturator nerve and sacral spinal nerves. $7,33,34$

\section{Conclusion}

Schwannomas are capillary tumors of the myelin sheath, which, for the most part, have benign behavior. They may present asymptomatic or with local symptomatology, evolving with paresthesia, anesthesia and pain, due to nervous compression (mass effect). Imaging tests such as the US and MRI help in the diagnosis. Macroscopically, they present eccentric growth, promoting the centrifugal displacement of the axonal fibers. This feature enables its surgical enucleation without compromising the nerve fibers. When it is approached by experienced professionals and with adequate techniques, the patients do not usually have motor sequelae.

Conflicts of Interest

The authors have none to declare.

\section{References}

1 Gosk J, Gutkowska O, Urban M, Wnukiewicz W, Reichert P, Ziółkowski P. Results of surgical treatment of schwannomas arising from extremities. BioMed Res Int 2015;2015:547926

2 Louis DN, Ohgaki H, Wiestler OD, Cavenee WK. WHO Classification of tumors of the Central Nervous System. Lyon: IARC; 2007

3 Sidani C, Saraf-Lavi E, Lyapichev KA, Nadji M, Levi AD. Acute presentation of brachial plexus schwannoma secondary to infarction. Neuroradiol J 2015;28(03):333-336

4 Farschtschi S, Mautner VF, Pham M, et al. Multifocal nerve lesions and LZTR1 germline mutations in segmental schwannomatosis. Ann Neurol 2016;80(04):625-628

5 Mackinnon SE. Nerve Surgery. New York: Thieme Medical Publishers; 2015

6 Schweitzer KM Jr, Adams SB Jr, Nunley JA II. Multiple schwannomas of the posterior tibial nerve: a case series. Foot Ankle Int 2013;34(04):607-611

7 Takahashi H, Hara M, Tsuboi K, et al. Laparoscopically resected obturator nerve schwannoma: A case report. Asian J Endosc Surg 2016;9(04):307-310

8 Gelpi E, Vicente-Pascual M. Clinical Neuropathology image 1-2017: incidental schwannoma of the posterior root. Clin Neuropathol 2017;36(01):3-4

9 Carter J, Ben-Ghashir N, Chandrasekar CR. Giant schwannoma of the medial plantar nerve. Foot 2016;26:4-6

10 Arabi H, Khalfaoui S, El Bouchti I, et al. Meralgia paresthetica with lumbar neurinoma: Case report. Ann Phys Rehabil Med 2015;58(06): 359-361

11 Madi S, Pandey V, Mannava K, Acharya K. A benign ancient schwannoma of the tibia nerve. BMJ Case Rep 2016;2016:1-2

12 Tadros AS, O'Boyle MK, Chen KC. Schwannoma of the posterior interosseous nerve. Ultrasound Q 2016;32(04):376-379

13 Xu SY, Sun K, Xie HY, Zhou L, Zheng SS, Wang WL. Hemorrhagic, calcified, and ossified benign retroperitoneal schwannoma: First case report. Medicine (Baltimore) 2016;95(30):e4318
14 Woodruff JM, Godwin TA, Erlandson RA, Susin M, Martini N. Cellular schwannoma: a variety of schwannoma sometimes mistaken for a malignant tumor. Am J Surg Pathol 1981;5(08):733-744

15 Khoo M, Pressney I, Hargunani R, Tirabosco R. Melanotic schwannoma: an 11-year case series. Skeletal Radiol 2016;45(01):29-34

16 Woodruff JM, Marshall ML, Godwin TA, Funkhouser JW, Thompson NJ, Erlandson RA. Plexiform (multinodular) schwannoma. A tumor simulating the plexiform neurofibroma. Am J Surg Pathol 1983;7(07):691-697

17 Jacoby LB, MacCollin M, Louis DN, et al. Exon scanning for mutation of the NF2 gene in schwannomas. Hum Mol Genet 1994;3(03): 413-419

18 Seizinger BR, Martuza RL, Gusella JF. Loss of genes on chromosome 22 in tumorigenesis of human acoustic neuroma. Nature 1986;322(6080):644-647

19 Bijlsma EK, Merel P, Bosch DA, et al. Analysis of mutations in the SCH gene in schwannomas. Genes Chromosomes Cancer 1994;11 (01):7-14

20 Jacoby LB, MacCollin M, Barone R, Ramesh V, Gusella JF. Frequency and distribution of NF2 mutations in schwannomas. Genes Chromosomes Cancer 1996;17(01):45-55

21 Rouleau GA, Merel P, Lutchman M, et al. Alteration in a new gene encoding a putative membrane-organizing protein causes neurofibromatosis type 2. Nature 1993;363(6429):515-521

22 Trofatter JA, MacCollin MM, Rutter JL, et al. A novel moesin-, ezrin, radixin-like gene is a candidate for the neurofibromatosis 2 tumor suppressor. Cell 1993;72(05):791-800

23 Louis DN, Ramesh V, Gusella JF. Neuropathology and molecular genetics of neurofibromatosis 2 and related tumors. Brain Pathol 1995;5(02):163-172

24 Hitotsumatsu T, Iwaki T, Kitamoto T, et al. Expression of neurofibromatosis 2 protein in human brain tumors: an immunohistochemical study. Acta Neuropathol 1997;93(03):225-232

25 Huynh DP, Mautner V, Baser ME, Stavrou D, Pulst SM. Immunohistochemical detection of schwannomin and neurofibromin in vestibular schwannomas, ependymomas and meningiomas. J Neuropathol Exp Neurol 1997;56(04):382-390

26 Sainz J, Huynh DP, Figueroa K, Ragge NK, Baser ME, Pulst SM. Mutations of the neurofibromatosis type 2 gene and lack of the gene product in vestibular schwannomas. Hum Mol Genet 1994;3 (06):885-891

27 Ammoun S, Provenzano L, Zhou L, et al. Axl/Gas6/NFkBsignalling in schwannoma pathological proliferation, adhesion and survival. Oncogene 2013;•••:1-11

28 Leone PE, Bello MJ, Mendiola M, et al. Allelic status of 1p, 14q, and $22 \mathrm{q}$ and NF2 gene mutations in sporadic schwannomas. Int J Mol Med 1998;1(05):889-892

29 Warren C, James LA, Ramsden RT, et al. Identification of recurrent regions of chromosome loss and gain in vestibular schwannomas using comparative genomic hybridisation. J Med Genet 2003;40 (11):802-806

30 Chhabra A, Thakkar RS, Andreisek G, et al. Anatomic MR imaging and functional diffusion tensor imaging of peripheral nerve tumors and tumorlike conditions. AJNR Am J Neuroradiol 2013;34(04):802-807

31 Kasprian G, Amann G, Panotopoulos J, et al. Peripheral nerve tractography in soft tissue tumors: a preliminary 3-tesla diffusion tensor magnetic resonance imaging study. Muscle Nerve 2015;51(03): 338-345

32 Siqueira MG, Socolovsky M, Martins RS, et al. Surgical treatment of typical peripheral schwannomas: the risk of new postoperative deficits. Acta Neurochir (Wien) 2013;155(09):1745-1749

33 Deboudt C, Labat JJ, Riant T, Bouchot O, Robert R, Rigaud J. Pelvic schwannoma: robotic laparoscopic resection. Neurosurgery 2013;72(1, Suppl Operative)2-5, discussion 5

34 Possover M, Kostov P. Laparoscopic management of sacral nerve root schwannoma with intractable vulvococcygodynia: report of three cases and review of literature. JMinim Invasive Gynecol 2013;20(03):394-397 